\title{
Pengaruh Anemia Terhadap Remaja Indonesia yang Ambyar Hatinya
}

\author{
Amelia Putri Nur Wulandari \\ Institut Ilmu Kesehatan STRADA INDONESIA \\ Amheliawulandari27@gmail.com
}

\begin{abstract}
Abstrak
Latar Belakang : Masalah gizi yang biasa dialami rejama salah satunya adalah anemia. Anemia adalah keadaan dimana kadar hemoglobin $(\mathrm{Hb})$ lebih rendah dari nilai normal, yang ditandai dengan lesu, pusing, mata berkunang-kunang, dan wajah pucat. Sehingga dapat menyebabkan menurunnya aktivitas dan prestasi belajar karena kurangnya konsentrasi yang mengakibatkan ambyar hatinya. Tinjauan Pustaka : Ada beberapa jenis anemia yaitu anemia akibat kekurangan zat besi, anemia pada masa kehamilan, anemia akibat perdarahan, anemia aplastik, anemia hemolitik, anemia akibat penyakit kronis, anemia sel sabit, dan thalasemia. Dimana sebagian besar anemia disebabkan oleh kurangnya zat besi dan makanan yang dikonsumsi tidak mencukupi kebutuhan. Anemia dapat dihindari dengan makan makanan kaya zat besi, asam folat, vitamin B12 dan vitamin C, serta menghindari kafein yang berlebihan. Pembahasan : Tingginya angka kejadian anemia pada remaja karena kurangnya zat gizi makro (karbohodrat, protein, lemak) dan kurang gizi mikro (vitamin dan mineral). Kesimpulan : Meski tidak menular namun anemia sangat berbahaya karena bisa mempengaruhi kesehatan generasi penerus bangsa, perlu perhatian khusus untuk mengetahui penyebab terjadinya dan cara pencegahannya.
\end{abstract}

Kata Kunci : anemia, remaja, status gizi, hemoglobin

\section{Latar Belakang}

Remaja merupakan transisi dari masa kanak-kanak ke masa dewasa yang ditandai sejumlah perubahan biologis, kognitif, dan emosional. Pertumbuhan dan perkembangan remaja yang sangat pesat membutuhkan asupan makanan bergizi seimbang, termasuk yang kaya akan zat besi. Kekurangan zat besi akan menyebabkan remaja rentan terkena anemia. Anemia dapat menurunkan konsentrasi dan produktivitas sehingga mengakibatkan sulit belajar bagi remaja. Tidak hanya itu, anemia juga dapat berakibat buruk dikemudian hari saat dewasa.

Anemia adalah penyakit yang sering ditemui pada masyarakat Indonesia. Penyakit anemia merupakan suatu kondisi dimana tubuh kekurangan sel darah merah atau eritrosit atau hemoglobin. Hemoglobin sendiri adalah protein kaya zat besi yang memberikan warna merah pada darah dan berfungsi membawa oksigen dari paru-paru ke seluruh tubuh dan mengangkut karbon dioksida dari seluruh bagian tubuh ke paru-paru agar dapat dikeluarkan dari tubuh.

Faktor-faktor penyebab anemia adalah status gizi yang dipengaruhi oleh pola makanan, sosial ekonomi keluarga, lingkungan dan status kesehatan. Khumaidi (1989) 
mengemukakan bahwa faktor-faktor yang melatarbelakangi tingginya prevalensi anemia gizi besi di negara berkembang adalah keadaan sosial ekonomi rendah meliputi pendidikan orang tua dan penghasilan yang rendah serta kesehatan pribadi di lingkungan yang buruk.

Kekurangan kadar $\mathrm{Hb}$ dalam darah dapat menimbulkan gejala lesu, lemah, letih, lelah dan cepat lupa. Selain dapat menurunkan prestasi belajar dan produktifitas kerja, anemia juga dapat menurunkan daya tahan tubuh dan mengakibatkan mudah terkena infeksi. Upaya pencegahan dan penanggulangan anemia yang telah dilakukan selama ini ditujukan pada ibu hamil, sedangkan remaja putri secara dini belum terlalu diperhatikan.

Remaja sangat beresiko menderita anemia khususnya kurang zat besi. Diperkirakan 25\% remaja Indonesia mengalami anemia. Meski tidak menular namun anemia sangat berbahaya karena bisa memengaruhi derajat kesehatan calon bayinya kelak.

\section{Kasus/Masalah}

2.1. Pengertian anemia pada remaja

2.2. Jenis-jenis anemia

2.3. Penyebab anemia pada remaja

2.4. Pencegahan dan cara mengatasi anemia pada remaja

\section{Tinjauan pustaka}

\subsection{Pengertian anemia pada remaja}

Anemia adalah penurunan kuantitas sel-sel darah merah dalam sirkulasi atau jumlah hemoglobin berada dibawah batas normal. Gejala yang sering dialami antara lain lesu, lemah, pusing, mata berkunang-kunang, dan wajah pucat. Anemia dapat menimbulkan berbagai dampak pada remaja antara lain menurunkan daya tahan tubuh sehingga mudah terkena penyakit, menurunnya aktivitas dan prestasi belajar karena kurangnya konsentrasi. Anemia defisiensi besi merupakan anemia yang paling sering terjadi pada remaja, karena kebutuhan yang tinggi untuk pertumbuhan. Anemia kurang zat besi lebih banyak terjadi pada remaja putri dibanding remaja putra.

Data Survei Kesehatan Rumah Tangga (SKRT) tahun 2004 menyatakan bahwa prevalensi anemia gizi pada remaja putri usia (10-18 tahun) 57,1\%. Remaja putri cenderung melakukan diet sehingga dapat menyebabkan asupan zat gizi berkurang termasuk zat besi. Selain itu adanya siklus menstruasi setiap bulan merupakan salah satu faktor penyebab remaja putri mudah terkena anemia.

Anemia kurang zat besi dapat dipengaruhi oleh beberapa faktor yaitu, kurangnya mengkonsumsi sumber makanan hewani sebagai salah satu sumber zat besi yang mudah diserap (heme iron), sedangkan bahan makanan nabati (non-heme iron) merupakan sumber zat besi yang tinggi tetapi sulit diserap sehingga dibutuhkan porsi yang besar untuk mencukupi kebutuhan zat besi dalam seharinya. Bisa juga disebabkan karena kekurangan zat gizi yang berperan dalam penyerapan zat besi 
seperti, protein dan vitamin C. Konsumsi makanan tinggi serat, tannin dan phytat dapat menghambat penyerapan zat besi. Berbagai faktor juga dapat mempengaruhi terjadinya anemia gizi besi, antara lain pola haid, pengetahuan tentang anemia, dan status gizi. Anemia defisiensi vitamin B12 dan folat juga sering terjadi pada remaja karena kurangnya pemenuhan zat gizi tersebut.

Usia 12-14 tahun termasuk dalam masa peralihan dari remaja awal ke remaja akhir yang merupakan masa pencarian identitas dan remaja cepat sekali terpengaruh oleh lingkungan. Kecemasan akan bentuk tubuh membuat remaja sengaja tidak makan atau memilih makan di luar. Kebiasaan ini dapat mengakibatkan remaja mengalami kerawanan pangan yang berhubungan dengan asupan zat gizi yang rendahdan berisiko pada kesehatannya termasuk anemia. Berdasarkan Riskesdas tahun 2007 prevalensi anemia remaja usia $\leq 14$ tahun di Indonesia sebanyak $12,8 \%$.

Anemia pada remaja adalah suatu keadaan kadar hemoglobin dalam darah lebih rendah dari nilai normal. Nilai batas ambang untuk anemia menurut WHO 2001 adalah untuk umur 5-11 tahun $<11,5 \mathrm{~g} / \mathrm{L}, 11-14$ tahun 5 2,O g/L, remaja diatas 15 tahun untuk anak perempuan $<12, \mathrm{O} \mathrm{g} / \mathrm{L}$ dan anak laki-laki $<3, \mathrm{O} \mathrm{g} / \mathrm{L}$.

\subsection{Jenis-jenis anemia}

\section{Anemia akibat kekurangan zat besi}

Kekurangan zat besi membuat tubuh tidak mampu menghasilkan hemoglobin (Hb). Kondisi ini bisa terjadi akibat kurangnya asupan zat besi dalam makanan, atau karena tubuh tidak mampu menyerap zat besi, misalnya akibat penyakit celiac.

\section{Anemia pada masa kehamilan}

Ibu hamil memiliki nilai hemoglobin yang lebih rendah dan hal ini normal. Meskipun demikian, kebutuhan hemoglobin meningkat saat hamil, sehingga dibutuhkan lebih banyak zat pembentuk hemoglobin, yaitu zat besi, vitamin B12, dan asam folat. Bila asupan ketiga nutrisi tersebut kurang, dapat terjadi anemia yang bisa membahayakan ibu hamil maupun janin.

\section{Anemia akibat perdarahan}

Anemia dapat disebabkan oleh perdarahan berat yang terjadi secara perlahan dalam waktu lama atau terjadi seketika. Penyebabnya bisa cedera, gangguan menstruasi, wasir, peradangan pada lambung, kanker usus, atau efek samping obat, seperti obat antiinflamasi nonsteroid (OAINS).

\section{Anemia aplastik}

Anemia aplastik terjadi ketika kerusakan pada sumsum tulang membuat tubuh tidak mampu lagi menghasilkan sel darah merah dengan optimal. Kondisi ini diduga dipicu oleh infeksi, penyakit autoimun, paparan zat kimia beracun, serta efek samping obat antibiotik dan obat untuk mengatasi rheumatoid arthritis. 


\section{Anemia hemolitik}

Anemia hemolitik terjadi ketika penghancuran sel darah merah lebih cepat daripada pembentukannya. Kondisi ini dapat diturunkan dari orang tua, atau didapat setelah lahir akibat kanker darah, infeksi bakteri atau virus, penyakit autoimun, serta efek samping obat-obatan, seperti paracetamol, penisilin, dan obat antimalaria.

\section{Anemia akibat penyakit kronis}

Beberapa penyakit dapat memengaruhi proses pembentukan sel darah merah, terutama bila berlangsung dalam jangka panjang. Beberapa di antaranya adalah penyakit Crohn, penyakit ginjal, kanker, rheumatoid arthritis, dan HIV/AIDS.

\section{Anemia sel sabit (sickle cell anemia)}

Anemia sel sabit disebabkan oleh mutasi (perubahan) genetik pada hemoglobin. Akibatnya, hemoglobin menjadi lengket dan berbentuk tidak normal, yaitu seperti bulan sabit. Seseorang bisa terserang anemia sel sabit apabila memiliki kedua orang tua yang sama-sama mengalami mutasi genetik tersebut.

\section{Thalasemia}

Thalasemia disebabkan oleh mutasi gen yang memengaruhi produksi hemoglobin. Seseorang dapat menderita thalasemia jika satu atau kedua orang tuanya memiliki kondisi yang sama.

\subsection{Penyebab anemia pada remaja}

Menurut WHO (2001), batas ambang anemia untuk wanita usia 11 tahun keatas adalah apabila konsentrasi atau kadar hemoglobin dalah darah kurang dari 12 g/dl. Penggolongan jenis anemia menjadi ringan, sedang, dan berat belum ada keseragaman mengenai batasannya, namun untuk mempermudah pelaksanaan pengobatan dan mensukseskan program lapangan, menurut ACC/SCN (1991), anemia dapat digolongkan menjadi tiga :

$\begin{array}{ll}\text { Anemia Ringan } & \text { hb } 10.0-11.9 \mathrm{~g} / \mathrm{dl} \\ \text { Anemia Sedang } & \text { hb } 7.0-9.9 \mathrm{~g} / \mathrm{dl} \\ \text { Anemia Berat } & \mathrm{hb}<7.0 \mathrm{~g} / \mathrm{dl}\end{array}$

Sebelum terjadi anemia biasanya terjadi kekurangan zat besi secara perlahanlahan. Pada tahap awal, simpanan zat besi yang berbentuk ferritin dan hemosiderin menurun dan absorpsi besi meningkat. Daya ikat besi (iron binding capacity) meningkat seiring dengan menurunnya simpanan zat besi dalam sumsum tulang dan hati. Ini menandakan berkurangnya zat besi dalam plasma. Selanjutnya zat besi yang tersedia untuk pembentukan sel-sel darah merah (sistem eritropoesis) di dalam sumsum tulang berkurang dan terjadi penurunan jumlah sel darah merah dalam jaringan. Pada tahap akhir, hemoglobin menurun (hypocromic) dan eritrosit mengecil (microcytic) dan terjadi anemia gizi besi (Wirakusumah 1998). 
Anemia dapat disebabkan oleh beberapa faktor. Menurut Depkes (1998), anemia terjadi karena :

(1) kandungan zat besi makanan yang dikonsumsi tidak mencukupi kebutuhan

(2) meningkatnya kebutuhan tubuh akan zat besi

(3) meningkatnya pengeluaran zat besi dari tubuh.

Menurut Biesalski dan Erhardt (2007), Penyebab utama anemia yang paling umum diketahui adalah :

(1) Kurangnya kandungan zat besi dalam makanan

(2) Penyerapan zat besi dari makanan yang sangat rendah

(3) Adanya zat-zat yang menghambat penyerapan zat besi

(4) Adanya parasit di dalam tubuh seperti cacing tambang atau cacing pita, atau kehilangan banyak darah akibat kecelakaan atau operasi.

Defisiensi zat besi dari makanan biasanya menjadi faktor utama. Jika zat besi yang dikonsumsi terlalu sedikit atau bioavailabilitasnya rendah atau makanan berinteraksi dengan membatasi absorpsi yang dibutuhkan tubuh untuk memenuhi kebutuhan zat besi, cadangan zat besi dalam tubuh akan digunakan dan hal tersebut dalam menimbulkan defisiensi zat besi (Gleason \& Scrimshaw 2007). Defisiensi zat gizi seperti asupan asam folat dan vitamin A, B12, dan C yang rendah dan penyakit infeksi seperti malaria dan cacingan dapat pula menimbulkan anemia (WHO 2001).

3.4. Pencegahan dan cara mengatasi anemia pada remaja

Anemia pada remaja bisa dihindari dengan melakukan beberapa hal, diantaranya adalah :

- Makanan kaya zat besi dan asam folat, seperti daging, sereal, kacang-kacangan, sayuran berdaun hijau gelap, roti, dan buah-buahan.

- Makanan kaya vitamin B12, seperti susu dan produk turunannya, serta makanan berbahan dasar kacang kedelai, seperti tempe dan tahu.

- Buah-buahan kaya vitamin $\mathrm{C}$, misalnya jeruk, melon, tomat, dan stroberi.

- Menghindari kafein yang berlebihan, terutama setelah makan.

- Memilih bahan makanan yang meningkatkan hemoglobin dalam tubuh.

- Menghindari konsumsi makanan atau minuman yang menghambat penyerapan zat besi serta konsumsi suplemen.

Untuk mengetahui apakah asupan nutrisi Anda sudah cukup, berkonsultasilah dengan dokter spesialis gizi. Bila Anda memiliki keluarga penderita anemia akibat kelainan genetik, seperti anemia sel sabit atau thalasemia, konsultasikan dengan dokter sebelum merencanakan kehamilan, agar kondisi ini tidak terjadi pada anak. 
Anemia merupakan keadaan yang dapat dicegah. Tetapi, jika sudah telanjur terjadi maka penanganannya harus segera dilakukan. Berikut ini merupakan beberapa cara untuk mengatasi anemia pada remaja, yaitu :

1. Ketahui penyebabnya

Untuk mengatasi anemia harus diketahui dulu apa penyebabnya. Karena banyak sekali penyebab terjadinya anemia, maka diperlukan pemeriksaan fisik dan pemeriksaan penunjang seperti cek darah untuk mengetahui penyebabnya.

Apabila disebabkan oleh infeksi seperti cacingan, anak perlu diberikan obat cacing untuk menghentikan infeksi. Apabila terjadi perdarahan, maka transfusi darah dapat menjadi pilihan untuk mengatasi kondisi anemia.

2. Terapkan pola makan yang baik

Mengonsumsi makanan yang sehat dan bergizi sangat memengaruhi kecukupan kebutuhan nutrisi anak. Dalam pencegahan dan mengatasi keadaan anemia, sebaiknya berikan sumber makanan yang tinggi akan zat besi.

Beberapa makanan yang mengandung zat besi antara lain daging merah, hati ayam, kacang-kacangan, bayam dan brokoli.

Pada saat mengonsumsi makanan yang mengandung zat besi, sebaiknya jangan memberikan teh dan susu di waktu berdekatan. Karena kandungan pada keduanya dapat mengganggu penyerapan zat besi di saluran pencernaan.

3. Konsumsi makanan yang mengandung vitamin $\mathrm{C}$

Selain mengonsumsi makanan yang kaya akan zat besi, jangan lupakan juga asupan tinggi vitamin C. Sebab, vitamin C dapat membantu meningkatkan penyerapan zat besi di dalam saluran cerna. Anda dapat memberikan jeruk, stroberi, paprika, kiwi maupun jambu dalam menu makanan pendamping anak.

4. Berikan suplementasi besi

Pemberian suplementasi besi untuk remaja dapat dilakukan guna untuk mempercepat kenaikan kadar hemoglobin. Di Indonesia, pemberian suplementasi besi diutamakan untuk anak usia balita, terutama di usia 0-2 tahun.

Dosis yang diberikan pun berdasarkan berat badan anak, yaitu $1 \mathrm{mg} / \mathrm{kgBB} /$ hari selama 3 bulan untuk anak usia 2-12 tahun. Meskipun diberikan suplementasi besi, pola makan yang baik tetap harus dijaga dan dipertahankan. 


\section{Pembahasan}

Ada beberapa faktor yang memicu terjadinya masalah gizi pada usia remaja seperti kebiasaan makan yang salah, pemahaman gizi yang keliru dimana tubuh yang langsing menjadi idaman para remaja sehingga kebutuhan gizi tidak terpenuhi, dan kesukaan yang berlebihan terhadap makanan tertentu contohnya makanan cepat saji (fast food).

Semakin tinggi remaja yang memiliki status gizi kurang maka semakin tinggi angka kejadian anemia pada remaja. Status gizi pada remaja di Indonesia meliputi kurang zat gizi makro (karbohodrat, protein, lemak) dan kurang gizi mikro (vitamin dan mineral). Apabila status gizi tidak normal maka dikhawatirkan status zat besi juga tidak baik, sehingga dapat menyebabkan anemia.

Anemia adalah menurunnya jumlah hemoglobin dari batas normal sehingga tidak dapat memenuhi fungsinya untuk membawa oksigen dalam jumlah yang cukup ke jaringan perifer. Nilai batas normal kadar hemoglobin untuk remaja putri adalah $<12$ gram/dL. Anemia dapat disebabkan oleh karena gangguan pembentukan eritrosit oleh sumsum tulang, kehilangan darah keluar dari tubuh (perdarahan), proses penghancuran eritrosit dalam tubuh sebelum waktunya (hemolisis), kurangnya asupan zat besi, vitamin $\mathrm{C}$, vitamin B12 dan folat.

Kekurangan kadar $\mathrm{Hb}$ dalam darah dapat menimbulkan gejala lesu, lemah, letih, lelah dan cepat lupa. Selain dapat menurunkan prestasi belajar dan produktifitas kerja, anemia juga dapat menurunkan daya tahan tubuh dan mengakibatkan mudah terkena infeksi. Upaya pencegahan dan penanggulangan anemia yang telah dilakukan selama ini ditujukan pada ibu hamil, sedangkan remaja putri secara dini belum terlalu diperhatikan. Padahal remaja sangat beresiko menderita anemia khususnya kekurangan zat besi. Diperkirakan $25 \%$ remaja Indonesia mengalami anemia.

\section{Kesimpulan}

Meski tidak menular namun anemia sangat berbahaya karena bisa mempengaruhi derajat kesehatan generasi penerus bangsa yang ambyar hatinya. Karena kekurangan kadar $\mathrm{Hb}$ dalam darah dapat menimbulkan gejala lesu, lemah, letih, lelah dan cepat lupa. Selain dapat menurunkan prestasi belajar dan produktifitas kerja, anemia juga dapat menurunkan daya tahan tubuh dan mengakibatkan mudah terkena infeksi. Maka dari itu perlu perhatian khusus untuk mengetahui penyebab terjadinya anemia dan cara pencegahannya yaitu dengan mengkonsumsi makanan kaya zat besi, asam folat, vitamin B12 dan vitamin $\mathrm{C}$, serta menghindari kafein yang berlebihan. 


\section{Daftar Pustaka}

Abdulsalam M, Daniel A. 2002. Diagnosis, Pengobatan dan Pencegahan Anemia Defisiensi Besi. Sari Pediatri, 4(2), September: $74-77$.

Arumsari E. 2008. Faktor Risiko Anemia Pada Remaja Putri Peserta Program Pencegahan dan Penanggulangan Anemia Gizi Besi (PPAGB) di Kota Bekasi. Bogor : Institut Pertanian Bogor.

Indartanti D, Kartini A. 2014. Hubungan Status Gizi Dengan Kejadian Anemia Pada Remaja Putri. Semarang. Journal of Nutrition College, 3(2), 33-39.

Kemenkes RI. 2013-2014. Prevalensi anemia di Indonesia.

Permaesih D, Herman S. 2005. Buletin Penelitian Kesehatan: Faktor-Faktor Yang Mempengaruhi Anemia Pada Remaja. Puslitbang Gizi dan Makanan, Badan Litbangkes. 33(4), 162-17. 